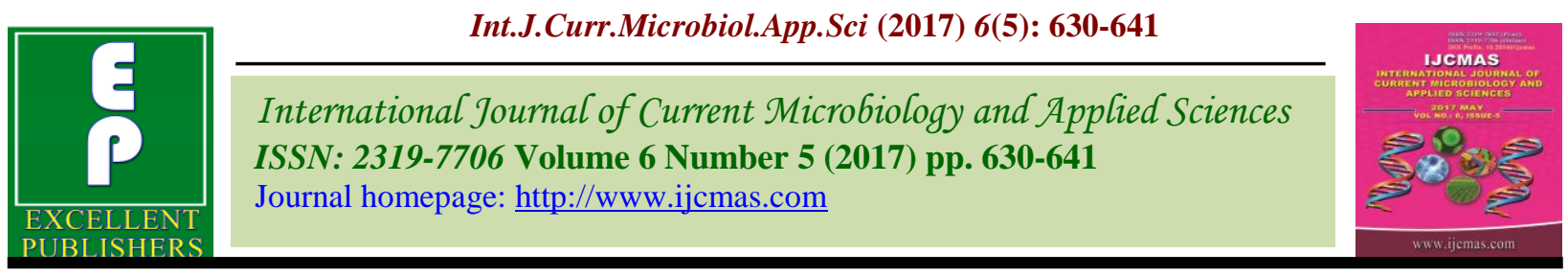

Original Research Article

https://doi.org/10.20546/ijcmas.2017.605.073

\title{
Studies on Occurrence of Invasive Salmonella spp. from Unorganised Poultry Farm to Retail Chicken Meat Shops in Mumbai City, India
}

\author{
R.N. Waghamare*, A.M. Paturkar, R.J. Zende, V.M. Vaidya, R. S. Gandage, \\ N.B. Aswar and R.S. Khilari \\ Department of Veterinary Public Health, Bombay Veterinary College, Parel Mumbai-12, India \\ *Corresponding author
}

\section{A B S T R A C T}

The present study was planned to estimate occurrence of invasive Salmonella spp. in retail chicken supply chain of Mumbai and quantifying Salmonella at crucial stages of

\begin{tabular}{|l|}
\hline Ke y w or d s \\
Poultry farms, \\
retail chicken \\
processing, \\
Salmonella \\
contamination, \\
MPN quantification, \\
invA.
\end{tabular}
processing by the Most Probable Number (MPN) and confirmation by invA gene by PCR assay. A total of $18(\mathrm{n}=108)$ farm samples were found to be positive for Salmonella with prevalence of $16.66 \%$ and statistical significance was observed amongst different sources at farm $(p=0.027)$. Highest prevalence of Salmonella spp. was noticed in litter samples $(50.00 \%)$ followed by cloacal swabs $(25.00 \%)$, water utensil swabs $(25.00 \%)$, faeces $(16.66 \%)$, water $(16.66 \%)$, wall dust $(8.33 \%)$ and worker hand $(8.33 \%)$. Over all prevalence of Salmonella spp. amongst various samples in retail shop was found to be $19.04 \%$. Out of 42 different chicken retail shop samples analysed03 (7.14 \%) swab samples of chopping board found positive while one sample each from water and swab samples of worker hand, platform, knife, and cloaca were found positive. Amongst 24 swab samples collected from chicken carcasses at various chicken processing stages, highest rate of contamination (50\%) was observed in post defeathering and post evisceration stages of processing with average count of 1.88 and $2.11, \log$ MPN count $/ 10 \mathrm{~cm}^{2}$ respectively. Out of 34 Salmonella isolates obtained in this study, 31 isolates showed positive amplification of $284 \mathrm{bp}$ fragment specific for the invA gene with $91.17 \%$ detection level. Thus, study revealed that poultry litter at farm and post defeathering and post evisceration stages at retail chicken processing, are critical sources of cross contamination of invasive Salmonella spp.

\section{Introduction}

Salmonella serotypes are significant zoonotic pathogens and cause a wide range of human diseases such as enteric fever, gastroenteritis and bacteremia in human and animals (Winokur et al., 2000 and Bennasar et al., 2000). Human salmonellosis is frequently associated with the consumption of poultry products (CDC, 2008; Hanning et al., 2009; Kang et al., 2009 and Pires et al., 2012). Contaminated poultry products are among the important sources for food-borne outbreaks in humans and Salmonella are isolated more often from poultry and poultry products (Habtamu et al., 2011; Kabir, 2010 and Linam and Gerber, 2007). As Salmonellosis is one of the most important foodborne diseases, few countries have a surveillance system that estimates the burden of salmonellosis in human populations (Flint et al., 2007 and WHO, 2005). Risk factors for colonization by Salmonella include season, hatchery of origin, feed mills, litter, water and 
various hygienic measures (Rose et al., 1999; Skov et al., 1999; Cardinale et al., 2004). Bryan and Doyle (1995) stated that commercially reared birds are in constant contact with litter and dust, both of which can be a source of contamination. Barnes, (1972) also mentioned that Salmonella contamination of birds may occur before, during or after the grow-out phase of production.

Indian broiler production has been growing, with an annual growth rate of 11.44 percent, production of 3.725 million tons (Index Mundi, 2015). In India, chicken is slaughtered at both industrial as well as at retail level but 95\% chicken is slaughtered at retail level, while the remaining is slaughtered at industrial level (Badhe et al., 2013).Probability of cross contamination of raw chicken at retail level shops increases due to poor slaughtering practices, poor personal hygiene and poor cleaning. In India common sanitary problems that occur during the slaughtering and handling of poultry are hygienic condition and cleanliness of contact surfaces. Different genes like Inv, Spv, and Stn have been identified as major virulence genes responsible for pathogenic salmonellosis, the chromosomally located invasion gene invA being thought to trigger the invasion of Salmonellae into cultured epithelial cells (Asten and Dijk, 2005). Therefore it is important to evaluate the food safety risks because of pathogenic Salmonella along the production and retail processing and identification of effective control points or control strategies on the farm and at retail level chicken meat.

The present study was conducted to estimate occurrence of invasive Salmonella spp. in poultry farm environment of unorganized non- integrated broiler farms and six chicken retail shops in Mumbai using cultural isolation and enumeration by the Miniature Most Probable Number (MPN) method at stages of retail chicken meat production. Positive isolates were confirmed by amplifying invA gene which is unique to this genus and has been proved to be a suitable PCR target with a potential diagnostic application.

\section{Materials \& Methods}

\section{Sample Collection}

Sample collection from poultry farm: A total of 108 different samples were collected from randomly selected 12 unorganised nonintegrated poultry farms with capacity of 1500 -2000 birds, aged between 35 to 42 days and supplying birds to retail chicken meat shops located in vicinity of Mumbai. Samples includes cloacal swab from the poultry birds, feed, drinking water, litter sample from poultry house, fresh feaces and pooled swab from hands of the personnel working in the houses, wall dust, feeder and drinker.

Sample collection from retail chicken shops: A total of 66 stage wise post processing breast swabs samples of $10 \mathrm{~cm}^{2}$ area (post bleeding, post scalding, post defeathering and post evisceration), neck skin of carcass before and after evisceration, environmental samples (washing water, scalding water and carcass contact surfaces) and cloacal swabs were collected from six chicken processing establishments identified as retails chicken shops

Swab samples from $10 \mathrm{~cm}^{2}$ area were collected aseptically as per the standard methods described by (Gill and Jones, 2005).

Cultivation and isolation of Salmonella spp.

Qualitative evaluation: Isolation of Salmonella spp. from various samples collected was carried out as per ISO 6579. In brief pre-enrichment of the collected samples 
in Buffered Peptone Water as 1:10 dilution and then incubated aerobically at $37^{\circ} \mathrm{C}$ for 18 hours. $0.1 \mathrm{ml}$ inoculum was transferred to a tube containing $10 \mathrm{ml}$ of the Rappaport Vassiliadis Soy broth and then incubated at $41.5^{\circ} \mathrm{C}$ for 24 hours. From the enrichment culture, $10 \mu \mathrm{l}$ inoculum was further inoculated onto the surface of Xylose Lysine Deoxycholate (XLD)and Brilliant Green Agar (BGA) plates then incubated at $37^{\circ} \mathrm{C}$ for 24 hours. The plates containing characteristic colonies of Salmonella appearing as smooth colonies with black centre on XLD and red to pink on BGA were selected and the gram staining was performed. Colonies showing typical Gram negative, non spore forming short rod shaped appearance were further subjected to biochemical characterization with biochemically negative for hydrolysis of urea, positive for TSI with alkaline slant (red), acid butt (yellow) with $\mathrm{H}_{2} \mathrm{~S}$ gas production and positive citrate utilization considered as positive for Salmonella spp.

\section{Quantitative evaluation by miniature MPN technique}

Pre enriched swab samples and neck samples of poultry carcass collected at stages viz, before and after evisceration, were subjected for quantitative miniaturized most probable number described by Pavic et al., (2009), based on ISO 6579-2002. The swab sample suspension $1 \mathrm{ml}$ of a $10^{-1}$ dilution was pipetted into an U-bottomed 96 deep well plates (Genexy scientific, India). Serial decimal dilutions (100: $900 \mu \mathrm{l})$ were performed in BPW using a micropipette to the previously described final dilutions of $10^{-6}$ in a labelled 96 well $\mathrm{U}$ bottomed plates. All tubes were mixed by repeated aspiration. From each of the dilutions in the plasma tubes, $100 \mu \mathrm{l}$ aliquots were transferred into each of three wells (i.e. A1 to A3) across a another U-bottomed 96 deep well plates with each dilution in a subsequent row (i.e. $10^{-1}$ in row $\mathrm{A} 1-\mathrm{A} 3,10^{-2}$ in row $\mathrm{B} 1$ to $\mathrm{B} 3$ to a theoretical maximum dilution of $10^{-6}$ in row F1-F3), producing a 3-tube MPN. The plate was then covered with adhesive paraffin wax film and incubated $\left(37^{\circ} \mathrm{C}\right.$ for $\left.24 \mathrm{~h}\right)$. From each post incubated well, the total volume was transferred to a corresponding U-bottomed 96 deep well plates containing $500 \mu \mathrm{l}$ MSRV and then incubated $\left(42^{\circ} \mathrm{C}\right.$ for $\left.24 \mathrm{~h}\right)$.

White colour change from blue to colourless in a tube was considered as a presumptive positive for the presence of Salmonella, with all tubes (regardless of colour development) being confirmed by subculturing onto XLD agar $\left(37^{0} \mathrm{C}\right.$ for $\left.24 \mathrm{~h}\right)$. Following incubation, typical colonies were subcultured onto nutrient agar $\left(37^{0} \mathrm{C}\right.$ for $\left.24 \mathrm{~h}\right)$ and confirmed by biochemical test and molecular characterization by PCR assay. The combination of positive and negative results yielded a MPN data set.

MPN values were calculated using MPN data by Thomas' equation in MS EXCEL data sheet developed by Division of Mathematics in FDA/CFSAN (Blodgett, 2006).

\section{Molecular characterization of isolated strains using Polymerase chain reaction (PCR) assay}

Genomic DNA of Salmonella spp. was extracted as per the protocol of Rawool et al., (2007). Primers for Salmonella organism was used according Rahn et al., (1992) for invA gene. Sequence of forward primer (invA) was GTGAAATTATCGCCACGTTCGGGCA A) and reverse primer was TCATCGCACCGTCAAAGGAACC). DNA samples were amplified in a total of $25 \mu \mathrm{l}$ as the following: $2.5 \mu 1$ of 10x PCR Buffer, 1.5 $\mu \mathrm{ldNTP}$ Mix (10mM), $2 \mu \mathrm{l} \mathrm{MgCl}_{2}(50 \mathrm{mM})$ $1.25 \mu \mathrm{l}$ of forward primer, $1.25 \mu \mathrm{l}$ of reverse primer, $0.50 \mu \mathrm{l} \mathrm{Taq}$ polymerase (500U) $14.0 \mu \mathrm{l}$ of PCR grade water and $2 \mu \mathrm{l}$ of the template. 
The PCR was performed under the using conditions of primary denaturation: $94^{\circ} \mathrm{C} / 2$ min., secondary denaturation: $94^{\circ} \mathrm{C} / 30 \mathrm{sec}$, annealing: $65^{\circ} \mathrm{C} / 1 \mathrm{~min}$., extension: $72^{\circ} \mathrm{C} / 2$ min., No. of cycles: 30 and final extension: $72^{\circ} \mathrm{C} / 5$ min. Aliquots of amplified PCR products were electrophoresed in $1.5 \%$ agarose gel. The samples and a 100 bp DNA ladder were loaded in the wells in amount of $7 \mu 1$ of sample. A current of $90 \mathrm{~V}$ for 1 hour was passed on the horizontal electrophoresis unit. Specific amplicons were observed under ultraviolet transillumination compared with the marker. The gel was photographed by a gel documentation system and the data were analyzed.

\section{Results and Discussion}

\section{Prevalence of Salmonella spp. from farm samples}

Study revealed that $12(16.66 \%)$ out of 108 samples were positive for Salmonella spp. in the environment of poultry farms located in vicinity of Mumbai city (Table: 01).There is significant difference $(\mathrm{p}=0.02)$ between sources in the farm and Salmonella occurrence. Results are comparable with study of Ahmed et al., (2014) who reported $11.1 \%$ of prevalence of Salmonella spp in the environment of broiler poultry farms of Khartoum, Sudan. Also Al-Zenki et al., (2007) who reported 5.4\% prevalence from farm samples collected in Kuwait, this may be attributed hygienic measures applied. Kumar et al., (2014) in India reported 0\%and15.6\% prevalence of Salmonella under intensive production system and free-range system, respectively.

This study showed that $6(50 \%)$ Salmonella spp. were isolated from litter. Salmonella from litter can lead to heavy contamination of the bird's feathers and feet which increases the probability to recover the organism from carcasses in poultry processing plants due to fecal shedding onto the litter (Trampel et al., 2000). Results are in agreement with Scur et al., (2014) who observed $61.9 \%$ prevalence of Salmonella spp. from litter samples. This study showed that there was a negative detection for Salmonella spp from feed and feeder swabs which confirm that use of heat treated feed material and proper storage conditions. Presence of Salmonella spp. in Drinker swabs $(25.00 \%)$ and drinking water (16.66\%) confirm that Salmonellae may originate either from faeces/litter or from water already contaminated by pathogenic organisms. The result pertaining to feed and water are opposite to the report of Alali et al., (2010) who has reported $27.5 \%$ and $0.00 \%$ prevalence of Salmonella from feed and water samples of conventional farms, respectively. El Hussein et al., (2010) who reported 7.23\% prevalence from poultry drinking water which may be attributed to the variation in the numbers of collected samples.

Positive cloacal swabs $(25.00 \%)$ and faeces $(16.66 \%)$ indicate current infection in the flocks which is attributed to horizontal transmission from poultry environment. Dust in the poultry houses in large amount may also be a hazard, since dust has been recognized as a vehicle of transmission of Salmonella when large numbers of organisms are present (Harbaugh et al., 2006) a positive wall dust swab $(8.33 \%)$ in our study confirms the same. The present result supports the report of Musa et al., (2014) and Corrique and Davies (2008) who reported that faeces/litter and dusts are the matrices of choice for Salmonella isolation and sources of cross contamination. This study also revealed that $01(8.3 \%)$ hand swabs was positive for Salmonella which confirms cross contamination. Similarly Ahmed et al., (2014) reported 01(5.6\%) hand swab was positive for Salmonella. 
The results are in agreement with Abunna et al., (2016), Marin et al., (2011) and ALIedani et al., (2014) who recovered Salmonella from various environmental samples mentioned in our study.Horizontal transmission can occur by direct bird-to-bird contact, ingestion of contaminated feces or litter, contaminated water, personnel, farm and personal equipment, and a variety of other sources (Nakamura et al., 1997; Nakamura et al., 1994 and Lahellec and Colin, 1985).

Variation in prevalence were reported by Agada et al., (2014) $10.9 \%$ in Nigeria, AlAbadi and Al-Mayah, (2012) 9.2\% in Iraq and Jahan et al., (2012) $45 \%$ in Bangladesh. Abbuna et al., (2016) stated that differences in prevalence might be due to the difference in study design, isolation technique, different in sample type and difference in geographical location.

\section{Prevalence of Salmonella spp. at chicken retail shop}

Over all 42 samples comprising of washing water, scalding water, swabs of worker hand, platform, chopping board, knife, and cloacal swab were analysed for Salmonella spp. Out of 42 samples $08(19.04 \%)$ samples found positive. Surprisingly in used scalding water samples were negative, that might be because of high temperature of water. Out of individual 6 samples of all category 03 (7.14 $\%$ ) swab samples of chopping board found positive while one sample each from water and swab samples of worker hand, platform, knife, and cloaca were found positive. Olayinka, and Adeyanju (2014) reported 23.8, 11.90 and 0.00 per cent occurrence of Salmonella spp. from knives, weighing scales and wooden tables, respectively. Costerton et al., (1999) stated that Salmonella spp. noted as common contaminants of equipment used in processing of meat which are able to produce biofilm. Thiruppathi et al., (2004) observed Salmonella cross-contamination in retail chicken outlets in Chopping boards at $(18.75 \%)$ and the butcher's hands (14.29\%) followed by knives and the weighing balance tray. Study conducted by Ali et al., (2010) to find out microbial contamination of raw meat and its environment in retail shops in Karachi, Pakistan and reported $29 \%$ distribution of Salmonella in meat samples but zero detection of Salmonella from meat cutting surfaces (knives, wooden boards, weigh scales and meat mincers) and environmental surface swabs. Higher occurrence of Salmonella spp. in retail chicken shop is may be due lack of adherence to good hygienic practices and poor management practices on the farms.

A total of 24 swab samples were collected from chicken carcass at various chicken processing stages at retail shop along with 6 neck samples of eviscerated carcasses. Statistically non-significant difference was observed amongst different processing stages $(p=0.43)$. Highest rate of contamination (50 $\%)$ was observed in post defeathering and post evisceration stages of processing. While only one swab samples post bleeding and post scalding stages were positive. Out 06 post eviscerated carcass neck skin samples two samples were found positive, being at the lowest point in terms of gravity, neck skin may accumulate bacterial particles from runoff from washing (Table No: 2).The handling and processing of retail chicken needsto be improved to reduce the Salmonella incidence level in these stages along with washing of carcasses before and after evisceration. In similar study conducted by Morris and Wells (1970) at processing plants noticed $13.2 \%$ and $7 \%$ level of contamination after picking and after evisceration, respectively. Difference in the occurrence might be due to mechanical and non-mechanical processing operations. The level of Salmonella in live birds brought 
for slaughter in retail markets might be very low but during processing under unhygienic stages carcasses were contamination by environmental sources. The previous studies as reported by other researchers only focused on the prevalence of Salmonella in chicken carcasses or chicken cuts and environment. This could explain the new way of detecting cross contamination of Salmonella which focused on the occurrence of Salmonella at different stages of retail chicken processing.

Quantification of Salmonella spp. by miniature MPN technique

As defeathering and evisceration are the major site of cross-contamination in poultry processing (Notermans et al., 1980; Clouser et al., 1995), each of 6 Samples at post defeathering and post evisceration stages of chicken processing were collected and subjected for quantification of Salmonella spp. by miniature MPN technique. Three samples each from post defeathering and post evisceration stages were positive with average $\log$ MPN count $/ 10 \mathrm{~cm}^{2}$ of 1.88 and 2.11 , respectively (Table :03). Shashidhar et al., (2011) observed Salmonell $a$ load in the range of 1.30 to $120 \mathrm{MPN} / \mathrm{g}$ in the retail chicken sample similarly Straver et al., (2007) have reported that the number of Salmonella on chicken filets varied from 1 to $3.81 \log$ MPN per filets. Very little work has been done in India on the amount of this organism present on the carcasses during the processing stages. This is first attempt in India to quantify the Salmonella during chicken processing stages using miniature MPN method.

Detection of invasive gene of virulent Salmonella (invA) using polymerase chain reaction $(\mathbf{P C R})$

Out of 34 Salmonella isolates obtained from in this study 31 isolates showed positive amplification of $284 \mathrm{bp}$ fragment specific for the invA gene (common gene) from examined samples with $91.17 \%$ detection level (fig. 1).

Table.1 Occurrence of Salmonella spp. isolated from poultry farm environment and other Samples

\begin{tabular}{|c|c|c|c|c|}
\hline Sr. No & Type of Sample & $\begin{array}{c}\text { No of Samples } \\
\text { Collected }\end{array}$ & $\begin{array}{c}\text { No of Positive } \\
\text { Samples } \\
\end{array}$ & $\begin{array}{c}\text { Per cent } \\
\text { Prevalence }\end{array}$ \\
\hline 1 & Cloacal Swab & 12 & 3 & 25.00 \\
\hline 2 & Feed & 12 & 0 & 0.00 \\
\hline 3 & Drinking Water & 12 & 2 & 16.66 \\
\hline 4 & Litter & 12 & 6 & 50.00 \\
\hline 5 & Faeces & 12 & 2 & 16.66 \\
\hline 6 & $\begin{array}{l}\text { Worker Hand } \\
\text { Swab }\end{array}$ & 12 & 1 & 8.33 \\
\hline 7 & Wall Dust Swab & 12 & 1 & 8.33 \\
\hline 8 & FeederSwab & 12 & 0 & 0.00 \\
\hline 9 & DrinkerSwab & 12 & 3 & 25.00 \\
\hline & Total & 108 & 18 & 16.66 \\
\hline
\end{tabular}

(Poultry environmental samples $p=0.02$ ) 
Table.2 Occurrence of Salmonella Spp. isolated from retail chicken processing shop

\begin{tabular}{|l|l|c|c|}
\hline $\begin{array}{l}\text { Sr. } \\
\text { No. }\end{array}$ & Sample Source & $\begin{array}{c}\text { Number of Samples } \\
\text { Collected }\end{array}$ & $\begin{array}{c}\text { Salmonella Positive } \\
\text { Samples }\end{array}$ \\
\hline \multicolumn{4}{|c|}{ A) Environmental and other samples } \\
\hline 1 & Washing Water & 6 & $1(2.3)$ \\
\hline 2 & Scalding water & 6 & 0 \\
\hline 3 & Worker Hand & 6 & $1(2.3)$ \\
\hline 4 & Carcass Contact Platform & 6 & $1(2.3)$ \\
\hline 5 & Chopping Board & 6 & $3(7.14)$ \\
\hline 6 & Knife Swab & 6 & $1(2.3)$ \\
\hline 7 & Cloacal Swabs & 6 & $1(2.3)$ \\
\hline \multicolumn{4}{|c|}{ B) Sampling at different Processing Stages } \\
\hline & \multicolumn{4}{|c|}{6} \\
\hline 8 & Post Bleeding & 6 & $1(16.66)$ \\
\hline 9 & Post Scalding & 6 & $1(16.66)$ \\
\hline 10 & Post Defeathering & 6 & $3(50.00)$ \\
\hline 11 & Post Evisceration & 6 & $3(50.00)$ \\
\hline 12 & $\begin{array}{l}\text { Neck Sample of Post } \\
\text { eviscerated carcass }\end{array}$ & $\mathbf{3 0}$ & $2(33.33)$ \\
\hline & \multicolumn{3}{|c|}{$\mathbf{1 0}(\mathbf{3 3 . 3 3})$} \\
\hline
\end{tabular}

(Processing stages $p=0.43$ )

Fig.1 PCR products of 284 bp DNA fragment of Salmonella isolates

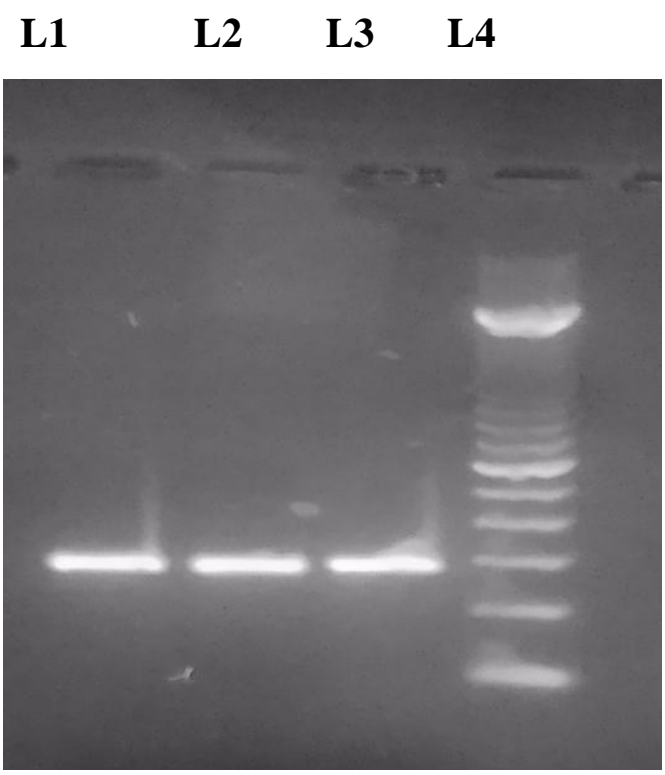

Lane1 and 2: $284 \mathrm{bp} \mathrm{PCR} \mathrm{products} \mathrm{of} \mathrm{Salmonella} \mathrm{isolates} \mathrm{recovered} \mathrm{from} \mathrm{poultry} \mathrm{farm} \mathrm{and}$ chicken retail shop samples; Lane 3: Standard Salmonella Typhimurium (MTCC 3224); Lane 4 (M): 100bp DNA Ladder 
Table.3 Quantification of Salmonella spp. in pre and post evisceration swab samples in chicken processing

\begin{tabular}{|l|l|c|c|c|}
\hline $\begin{array}{c}\text { Sr. } \\
\text { No }\end{array}$ & Processing Stage & Samples & $\begin{array}{c}\text { Number of } \\
\text { Positive samples }\end{array}$ & $\begin{array}{c}\text { Average log } \\
\text { MPN } \\
\text { Count/10cm }\end{array}$ \\
\hline 1 & Post Defeathering & 6 & 3 & 1.88 \\
\hline 2 & Post Evisceration & 6 & 3 & 2.11 \\
\hline & Total & 12 & 06 & \\
\hline
\end{tabular}

Results are in agreement with Ohtsuka et al., (2005) who reported $90 \%$ detection of Salmonella by PCR, whereas less than Salehi et al., (2005), Ozbey and Ertas (2006) and Samaxa et al., (2012) who reported $100 \%$ detection of Salmonella spp. by PCR. This may be attributed to variation due to targeting different genes and the concentration of DNA template added to the PCR reactions

In conclusion, this study revealed that the prevalence rate of Salmonella spp. in farms and chicken retail shops in Mumbai were $16.66 \%$ and $19.04 \%$ respectively. Highest prevalence of Salmonella spp. was noticed in litter samples followed by cloacal swabs and drinker swabs which would be considered as risk factors for cross contamination at farm level. Post defeathering and Post evisceration stages of processing are found critical stages of retail processing. Higher prevalence rate could be attributed to lack of adherence to good hygienic practices and poor management practices on the farms and retail chicken shop. Application of hygienic measures during farm management and processing stages may reduce the risk of Salmonellosis in human. Detection of the invA gene from isolated strains has revealed high risk of exposure to pathogenic strains of Salmonella spp. Data obtained in the study can be guide for the development of quantitative risk assessment models in chicken meat processing. The adoption of improved technology and strict hygiene measures can often reduce the risk of contamination of carcasses

\section{References}

Abadi and Mayah. 2012. Isolation and identification of Salmonella spp. from chicken and chicken environment in Basrah province. MSc thesis submitted to Department of Pathology and Poultry Diseases, College of Veterinary Medicine Basrah University, Basrah, Iraq.

Abunna, F., Bedasa, M., Beyene, T., Ayana, D., Mamo, B., and Duguma, R. 2016. Salmonella: Isolation and antimicrobial susceptibility tests on isolates collected from poultry farms in and around Modjo, Central Oromia, and Ethiopia. J. Ani. Poultry Sci., 5(2): 21-35

Agada, Abdullahi, Aminu, Odugbo, Chollom, Okeke and Okwori. 2014. Prevalence and risk factors associated with Salmonella species contamination of commercial poultry farms in Jos, Plateau State, Nigeria. World J. Biol. Biol. Sci., 2: 049-061

Alali, W.Q., Thakur, S., Roy, D.B., Martin, M.P. and Gebreyes, W.A. 2010. Prevalence and Distribution of Salmonella in Organic and Conventional Broiler Poultry Farms. Foodborne Pathogens and Dis., Vol: 7(11): 1363-1371

Ali, N.H., Farooqui, A., Khan, A., Khan, A.Y. 
and Shahana, U. Kazmi. 2010. Microbial contamination of raw meat and its environment in retail shops in Karachi, Pakistan. J. Infect. Dev. Ctries, 4(6): 382-388

Al-Zenki, S., Al-Nasser, A., Al-Safar, A., Alomirah, H., Al-Haddad, A. and Hendriksen, R.S. 2007. Prevalence and antibiotic resistance of Salmonella isolated from a poultry farm and processing plant environment in the State of Kuwait. Foodborne Pathogens and Dis., 4(3): 36773.

Angen, O., Skov, M.N., Chriel, M., Agger, J.F. and Bisgaard, M. 1996. A retrospective study on Salmonella infection in Danish broiler flocks. Prev. Vet. Med., 26: 223-237.

Asten, A.J. and Dijk, J.E. 2005. Distribution of "classic" virulence factors among Salmonella spp. FEMS Immunol. Med. Microbiol., 44(3): 251-259.

Badhe, S.K., Falroze, M.N. and Sudarshan, S. 2013. Prevalence of foodborne pathogens in markets samples of chicken meat in Bangalore, India. Indian J. Anim. Res., 47(3): 262-264.

Barnes, E.M. 1972. Food poisoning and spoilage bacteria in poultry processing. Vet. Rec., 90: 720-722.

Bennasar, A., Luna, G., Cabrer, B. and Lalucat, J. 2000. Rapid identification of Salmonella typhimurium, S. enteritidis and $\mathrm{S}$. virchow isolates by polymerase chain reaction based fingerprinting methods. Int. Microbiol., 3: 31-38.

Bryan, F.L. and Doyle, M.P. 1995. Health risks and consequences of Salmonella and Campylobacter jejuni in raw poultry. J. Food Prot., 58: 326-344.

Cardinale, E., Tall, F., Gueye, E.F., Cisse, M. and Salvat, G. 2004. Risk factors for Salmonella enterica subsp. enterica infection in senegalese broiler-chicken flocks. Prev. Vet. Med., 63: 151-161

Carrique, M. and Davies, R.H. 2008.
Sampling and bacteriological detection of Salmonella in poultry and poultry premises: a review, Rev. Sci. Tech., 27(3): 665-77.

Centers for Disease Control and Prevention. 2008. Annual listing of foodborne disease outbreaks. Outbreak surveillance data. Reported foodborne disease outbreaks and illnesses by etiology and food commodities, United States. Available at: http:www.cdc.gov/ food forneoutbreaks/outbreak_data.htm. Accessed 1 November 2011.

Clouser, C.S,. Doores, M., Mast, M.G. and Knabel, S.J. 1995. The role of defeathering in the contamination of turkey skin by Salmonella species and Listeria monocytogenes. Poult. Sci., 74: 723-731.

Costerton, J.W., Stewart, P.S. and Greenberg, E.P. 1999. Bacterial Biofilms: A Common Cause of Persistent Infections Sci., 284: 1318-1322.

Dione, M.M., Saha, D., Mohammed, N.I., Adegbola, R.A., Leven, M. and Antonio, M. 2011. Antimicrobial resistance and virulence genes of non typhoidal Salmonella isolates in The Gambia and Senegal. J. Infect. Dev. Ctries, 5: 765-775.

Flint, J.A., Duynhoven, Y.T., Angulo, F.J., DeLong, S.M., Braun, P., Kirk, M., Scallan, E., Fitzgerald, M., Adak, G.K., Sockett, P., Ellis, A., Hall, G., Gargouri, N,. Walke, H. and Braam, P. 2005. Estimating the burden of acute gastroenteritis, foodborne disease, and pathogens commonly transmitted by food: an international review. Clin. Infect. Dis., 41: 698-704.

George, K., Morris, G.K. and Wells, J.G. 1970. Salmonella Contamination in a Poultry-Processing Plant. Appl. Microbiol., 19(5): 795-799.

Habtamu, T.M., Rathore, R., Dhama, K. and Agarwal, R.K. 2011. Isolation, 
Identification and Polymerase Chain Reaction (PCR) Detection of Salmonella species from field materials of poultry origin. Int. J. Microbiol. Res., 2: $135-142$.

Hanning, I.B., Nutt, J.D., and Ricke, S.C. 2009. Salmonellosis outbreaks in the United States due to fresh produce: sources and potential intervention measures. Foodborne Pathog. Dis., 6: 635-648.

Harbaugh, E., Trampel, D., Wesley, I., Hoff, S., Griffith, R. and Hurd, H.S. 2006. Rapid aerosol transmission of Salmonella among turkeys in a simulated holding-shed environment. Poultry Sci., 85: 1693-1699

Index Mundi. 2015. India Broiler Meat (Poultry) Production by Year.

Jahan, L. Kabir, M. Mansurul, and M. Amin. 2013. Identification and antimicrobial resistance profiles of Salmonellae isolated from the broiler dressing plants associated with their environments. $A d v$. Res. J. Microbiol., 1: 1-9.

Kang, Z.W., Jung, J.H., Kim, S.H., Lee, B.K.,. Lee, D.Y., Kim, Y.J., Lee, J.Y., Won, H.K., Kim, E.H. and Hahn, T.W. 2009. Genotypic and phenotypic diversity of Salmonella Enteritidis isolated from chickens and humans in Korea. J. Vet. Med. Sci., 71: 14331438.

Kanki, M., Sakata, J., Taguchi, M., Kumeda, Y., Ishibashi, M., Kawai, T., Kawatsu, K., Yamasaki, W., Inoue, K. and Miyahara, M. 2009. Effect of sample preparation and bacterial concentration on Salmonella enterica detection in poultry meat using culture methods and PCR assaying of preenrichment broths. Food Microbiol., 26: 1-3.

Kumar, T., Rajora, V.R., Arora, N. 2014. Prevalance of Salmonella in pigs and broiler in the Tarai region of Uttarkhand, India, Indian
J. Med. Microbiol., Vol 32(1): 99-101.

Lahellec, C. and Colin, P. 1985. Relationship between serotypes of Salmonellae from hatcheries and rearing farms and those from processed poultry carcasses. $B r$. Poult. Sci., 26: 179-186.

Ledani, A.l., Khudor, M., and Oufi. 2014. Isolation and identification of Salmonella spp from poultry farms by using different techniques and evaluation of their antimicrobial susceptibilities. J. Vet. Resistance, 1: 234-239.

Linam, W.M. and Gerber, M.A. 2007. Changing epidemiology and prevention of Salmonella infections. Pediatric Infect. Dis. J., 26: 747-748.

Malorny, B., Lofstrom, C., Wagner, M., Kramer, N. and Hoorfar, J. 2008. Enumeration ofSalmonella bacteria in food and feed samples by real-time PCR for quantitative microbial risk assessment. Appl. Environ. Microbiol., 74: 1299- 304.

Marin, C., Balasch, S., Vega, S. and Lainez, M. 2011. Sources of Salmonella contamination during broiler production in Eastern Spain. Prev Vet. Med., 98(1): $39-45$.

Musa, I.W., Mansur, M.S., Sa'idu, L., Mohammed, B. and Aliyu, H.B. 2014 Poultry Environment and farm Practices Influencing the Isolation rate of MultiDrug Resistant Salmonella from water and Poultry feed in Zaria, Nigeria. $J$. Appl. Biol. Biotechnol., Vol. 2(01): 013016

Nakamura, A., Takagi, M., Takahashi, T., Suzuki, S. Sato, S., and Takehara, K. 1997. The effect of the flow of air on horizontal transmission of Salmonella enteritidis in chickens. Avian Dis., 41: 354-360.

Nakamura, M., Nagamine, N., Takahashi, T., Suzuki, S., Kijima, M., Tamura, Y., and Sato, S. 1994. Horizontal transmission 
of Salmonella enteritidis and effect of stress on shedding in laying hens. Avian Dis., 38: 282-288.

Notermans, S.F., Terbijhe, R.J., and Schothorst, M. 1980. Removing faecal contamination of broilers by spray cleaning during evisceration. Br. Poult. Sci., 21: 115-121.

NSW Food Authourity. 2011. NSW Retail Meat Food Safety Program, NSW/FA/FI024/1109.http://www.fooda uthority.nsw.gov.au/_Documents/indust ry_pdf/h igh-risk-retail-meat-premisesfood-safety-program.pdf

Ohtsuka, K., Yanagawa, K., Takatori, K. and Hara-Kudo, Y. 2005. Detection of Salmonella enterica in naturally contaminated liquid eggs by Loopmediated Isothermal Amplification, and characterization of Salmonella isolates. Appl. Environ. Microbiol., 71(11): 6730-6735.

Olayinka, I. and Adeyanju, G.T. 2014. Frozen Retail Poultry Meat Contact Surfaces as Sources of Salmonella and Escherichia Coli Contamination in Ibadan, Oyo State, Nigeria." American J. Epidemiol. Infect. Dis., 2(4): 81-85.

Ozbey, G. and Ertas, H.B. 2006. Salmonella spp. isolation from chicken samples and identification by Polymerase Chain Reaction. Bulgarian J. Vet. Med., 9(1): 67-73.

Pavic, A., Groves, P.J., Bailey, G. and Cox, J.M. 2010. A validated miniaturized MPN method, based on ISO 6579:2002, for the enumeration of Salmonella from poultry matrices, J. Appl. Microbiol., 109: 25-34.

Pires, S.M., Vieira, A.R., Perez, E., Wong, D.L.F. and Hald, T. 2012. Attributing human foodborne illness to food sources and water in Latin America and the Caribbean using data from outbreak investigations. Int. J. Food Microbiol., 152: $129-138$.
Rahn, K., De Grandis, S.A., Clarke, R.C., McEwen, S.A., Galán, J.E., Ginocchio, C., Curtiss, R. and Gyles, C.L. 1992. Amplification of aninvAgenesequence of Salmonella Typhimurium by Polymerase Chain Reaction as a specific method of detection of Salmonella. Mol. Cell Probes, 6(4): 271-9.

Rawool, D.B., Malik, S.V.S., Barbuddhe, S.B., Shakuntala, I. and Aurora, R. 2007. A multiplex PCR for detection of virulence associated genes in Listeria monocytogenes. Internet J. Food Safety, 9: 56-62.

Renwick, S.A., Irwin, R.J., Clarke, R.C., McNab, W.B., Poppe, C. and McEwen, S.A. 1992. Epidemiological associations between characteristics of registered broiler chicken flocks in Canada and the Salmonella culture status of floor litter and drinking water. Can. Vet. J., 33: 449-458.

Rose, N., Beaudeau, F., Drouin, P., Toux, J.Y., Rose, V. and Colin, P. 1999. Risk factors for Salmonella entericasub sp. enterica contamination in French broiler-chicken flocks at the end of the rearing period. Prev. Vet. Med., 39: 265-277.

Salehi, T.Z., Mahzounieh, M. and Saeedzadeh, A. 2005. Detection of invA gene in isolated Salmonella from broilers by PCR Method. Int. J. Poult. Sci., 4(8): 557-559

Salehi, Z.T., Mahzounieh, M., and Saeedzadeh, A. 2005. Detection of invA gene in isolated Salmonella from broilers by PCR method. Int. J. Poult. Sci., 4: 557- 559

Samaxa, R.G., Matsheka, M.I., Mpoloka, S.W. and Gashe, B.A. 2012. Prevalence and antimicrobial susceptibility of Salmonella Isolated from a variety of raw meat sausages in Gaborone (Botswana) retail stores. J. Food 
Protect., 75(4): 637-642.

Scur, M.C., Gisele da Silva, P.F., De Bona, E.A.M., Laís Dayane Weber, L.D., Alves, L.F.A. and Moura, A.C. 2014. Occurrence and antimicrobial resistance of Salmonella serotypes isolates recovered from poultry of Western Paraná, Brazil African J. Agri. Res., Vol. 9(9): 823-830.

Shashidhar, R., Srivastava, I. and Bandekar, J.R. 2011. Quantification of Salmonella in Food Samples from India Using the MINI-MSRVMPN and Modified MINIMSRV MPN Methods. J. Food Sci., 76: 564-567.

Skov, M.N., Angen, O., Chriel, M., Olsen, J.E. and Bisgaard, M. 1999. Risk factors associated with Salmonella enterica serovar typhimurium infection in Danish broiler flocks. Poult. Sci., 78: 848-854.

Straver, J.M., Janssen, A.F., Linnemann, A.R., van Boekel, M.A., Beumer, R.R. and Zwietering, M.H. 2007. Number of Salmonella on chicken breast filet at retail level and its implications for public health risk. J. Food Prot., 70: 2045-55.

Thiruppathi, S., Abdulla, M.H., Dorairaj, S.,
Sangeetha, S. and Perumalsamy, L. 2004. Salmonella Cross-contamination in Retail Chicken Outlets and the Efficacy of Spice Extracts on Salmonella enteritidis Growth Inhibition on Various Surfaces. Microbes and Environ., 19(4): 286-291.

Trampel, D.W., R.J. Hasiak, L.J. Hoffman, and M.C. Debey. 2000. Recovery of Salmonella from water, equipment, and carcasses in turkey processing plants. $J$. Appl. Poultry Res., 9: 29-34.

Winokur, P.L., Brueggemann, A., DeSalvo, D.L., Hoffmann, L,. Apley, M.D., Uhlenhopp, E.K., Pfaller, M.A., and Doern, G.V. 2000. Animal and human multidrug-resistant, cephalosporin-resistant Salmonella isolates expressing a plasmid mediated CMY-2 AmpC beta-lactamase. Antimicrobial Agents of Chemother., 44: 2777-2783.

World Health Organization. 2005. Drugresistant Salmonella. Fact sheet no. 139. Available

at: http://www.who.int/mediacentre/factshe ets/ fs139/en/. Accessed 8 September 2011.

\section{How to cite this article:}

Waghamare, R.N., A.M. Paturkar, R.J. Zende, V.M. Vaidya, N.B. Aswar and Khilari, R.S. 2017. Studies on Occurrence of Invasive Salmonella spp. In Unorganised Poultry Farm to Retail Chicken Meat shops in Mumbai City. Int.J.Curr.Microbiol.App.Sci. 6(5): 630-641. doi: https://doi.org/10.20546/ijcmas.2017.605.073 